\title{
"jSan Jorge, mata la araña!" (Rastros de la convivencia con las imágenes en el Siglo de Oro)
}

Una escena de la comedia de Lope de Vega La niñez del Padre Rojas, nos presenta a su protagonista en conversación con el arcángel Gabriel, a quien le comenta:

\author{
Cuando vocalmente rezo, \\ o hablo a Dios mentalmente, \\ le imagino como puedo \\ por las pinturas que he visto ${ }^{1}$
}

Estos versos nos introducen directamente en uno de los temas que más preocuparon a las autoridades eclesiásticas contrarreformistas, como es el de la eficacia doctrinal de la imagen sagrada. A través de pinturas o esculturas el fiel podía retener en su memoria personajes o situaciones que marcaban hitos en la genealogía e historia de su religión, y la Iglesia podía mostrar eficazmente la tradición que la avalaba. El concilio de Trento, en parte como reacción al racionalismo protestante, promovió una religiosidad que buscaba una adhesión de tipo sentimental del fiel. Y para lograrla, aparte de alentar particularismos locales del culto, recurrió fundamentalmente a medios plásticos, que sabía eran los que más persuasivamente podían incidir en el comportamiento de las masas de población. Por eso, desde finales del siglo XVI se multiplica el número de obras de arte y de ceremonias públicas que tienen como objeto la descripción o glorificación de dogmas o personajes que conforman las señas de identidad del catolicismo ${ }^{2}$.

1 Obras de Lope de Vega, ed. M. Menéndez Pelayo (Madrid: Atlas, 1963-1972), t. XII, p. $11 \mathrm{~b}$.

2 Sobre el tema véase, entre otros, E. MALE, L'art religieux de la fin du xve siécle, du xvme siécle et du XVume siécle (Paris: Albin Michel, 2." ed., 1951); P. FranCASTEL, La realidad figurativa (Buenos Aires: Emecé, 1970); C. CANedo-Arguelles, Arte y teoria; la Contrarreforma y España (Oviedo: Universidad, 1982); o P. MArtinEz-BURGos, Idolos e imágenes (Valladolid: Universidad, 1990). 
De la importancia que se otorgaba al arte como instrumento de religión nada hay más expresivo que la frecuencia con que, a partir de la Contrarreforma, surgieron tratados pictóricos escritos por teólogos o por personas vinculadas profesionalmente a la Iglesia. Entre los más importantes figuran los de Molano y Paleotti, redactados todavía en el siglo xvi y encaminados fundamentalmente a reglamentar y codificar la iconografía sacra, expurgándola de temas o detalles poco ortodoxos. En ellos se llama insistentemente la atención sobre el importante papel que al artista le toca jugar en la labor educadora y evangelizadora ${ }^{3}$. En España nos quedan varios ejemplos de este tipo de literatura, como el Arte de la pintura de Pacheco -que era familiar del Santo Oficio y dedica gran parte de su tratado a codificar la imagen sacra- ${ }^{4}$, la Copia de los pareceres de diversos teólogos sobre pinturas lascivas', El pintor christiano y erudito de Interián de Ayala, o los Diálogos del pintor christiano, que escribió antes de 1607 fray Diego de Arce y no han sido todavía identificados ${ }^{6}$. Esto ya de por sí supone alrededor de una quinta parte de los escritos peninsulares del Siglo de Oro dedicados a la pintura; pero es que además se puede decir que en el resto de los tratados los problemas dedicados a la imagen religiosa y su representación ocupan un lugar fundamental.

La importancia de las imágenes no radicaba sólo en lo eficaces que eran en general los medios plásticos para persuadir y facilitar la retención en la memoria de ideas, sucesos y personajes, sino que, en una sociedad mayoritariamente analfabeta, constituían uno de los escasos instrumentos (junto con los sermones) con que contaba la mayor parte de la población para acceder al conocimiento de la historia sagrada. En esa época se recurrió muy frecuentemente a frases de San Gregorio, San Juan Damasceno, San Basilio o el venerable Beda en las que se calificaba a la pintura como alibro de ignorantes. Los pintores madrileños, cuando en 1619 intentaron crear una academia de pintura, elevaron un memorial al rey en el que trataban de demostrar la necesidad de regular el ejercicio de su oficio mediante una institución de este tipo. Entre los principales argumentos que utilizaron para convencer de la importancia de su actividad figuraba que *Nuestra Santa Madre Iglesia, por

3 Véase el capítulo "El Concilio de Trento y el arte religioso", en Anthony BuUNT, La teoria de las artes en Italia (1450-1600) (Madrid: Cátedra, 1979), pp. 115-142. El tratado de Paleotti ha sido minuciosamente estudiado por P. PRODI, Ricerca sulla teorica delle arti figurative nella Riforma cattolica (Bolonia: Nuova Alfa, 1984).

+ Ed. J. Bassegoda (Madrid: Cátedra, 1990).

5 Data de 1632. Ha sido reproducida y comentada en Francisco Calvo SERRALler, Teoría de la pintura del Siglo de Oro (Madrid: Cátedra, 1981), pp. 327-260.

- Referencia a este tratado en Miguel HERRERO, Contribución de la literatura a la bistoria del arte (Madrid: C.S.I.C., 1943), pp. 138-139. 
este medio, como por lenguaje común y claro, y como por libro abierto se declara y da a entender más claramente, en especial a mujeres y gente idiota que no saben, o no pueden leer " ${ }^{7}$. Siete años después, Juan de Butrón, en una obra dedicada a la demostración del carácter noble y liberal de la pintura, hace también hincapié en su importantísima eficacia doctrinal:

Para los doctos, y letrados la Escritura basta, mas para los ignorantes, ¿qué maestro ay como la pintura? Leen en la tabla lo que deven seguir, y no pueden sacar de los libros: de donde nace, que aun los que más saben usan del libro de la pintura, porque más claramente entienden lo que los libros no les declaran ${ }^{8}$

Relacionado con esto se encuentra un tema hasta ahora escasamente tratado por los que se ocupan de la historia del arte o de la antropología de nuestro Siglo de Oro. Nos referimos a la existencia de distintos tipos de gustos y diferentes clases de percepciones de la obra artística, que no son más que el reflejo de unos niveles de educación y una composición social también muy variados, y que suponen relaciones distintas con la imagen sagrada. En esa época se admitían principalmente dos tipos de actitudes ante la imagen, que podemos sintetizar con los verbos "ver" y "mirar": el primero suponía un acercamiento fundamentalmente sensorial, mientras que el segundo, que estaba reservado sólo a las clases más cultas, implicaba también una aproximación racional y discursiva 9 . Pero además, en numerosas obras literarias se encuentran alusiones a lo que podríamos llamar "mirada ingenua"; esto es, a un tercer nivel de percepción que correspondería fundamentalmente a campesinos. Antes de pasar a describir sus características, hay que señalar que no es fácil decidir hasta qué punto es reflejo de la existencia de una gran desigualdad cultural entre unas masas urbanas que, aunque analfabetas, estaban acostumbradas a convivir con la literatura a través de numerosas obras de teatro, y con las artes plásticas por medio de grandes celebraciones o del rico ajuar de los templos de sus ciudades, y una población campesina

- Memorial de los pintores... Academia, en Calvo Serraller, op. cit., p. 165. Citas de este tipo pueden multiplicarse fácilmente. Así, Ioseph RODRíguEz, en su Sacro y solemne novenario... Valencia... San Iuan de la Mata y San Felix de Valois (Valencia: B. Macé, 1669), p. 216, escribe: "Es toda la pintura deste quadro mui natural, de gentil disposición, de mui buen gusto, y le franquea a todos, pues hasta los que no saben leer hallan en un lienço lo que podían en un libro, que este fue el fin de las pinturas, como dize el Serafin de las escuelas".

8 Discursos apologéticos en los que se defiende la ingenuidad del arte de la pintura (Madrid: Luis Sánchez, 1626), 36v.

9 Sobre el tema hemos tratado en: ‘Público, públicos e imágenes en el Madrid de 1622, Cuadernos de Arte e Iconografía, IV, 8 (1991), pp. 165-172; y en Lope de Vega $y$ las artes plásticas (Madrid: Universidad Complutense, 1992), pp. 39-58. 
que raramente tuvo acceso a este tipo de manifestaciones; o si se trata, en cambio, de un tópico literario que en parte ha pervivido hasta nuestros días.

' $\mathrm{El}$ caso es que abundan las alusiones al campesino inocente; en muchas de las cuales se presenta absorto y extrañado ante una obra de arte. Así, en el Canto IV de El Isidro aparecen estos versos:

$$
\begin{aligned}
& \text { Y como en tabla o pintura, } \\
& \text { señalando con la mano, } \\
& \text { pregunta el rudo villano: } \\
& \text { ¿Quién es aquella figura? } \\
& \text { al que ve más cortesano }{ }^{10}
\end{aligned}
$$

El tema es importante para estudiar las ideas que se tenían en la época sobre la naturaleza de la obra artística, pues nos está demostrando hasta qué punto se concebía ésta como un producto esencialmente civilizado. En lo que se refiere al objeto de este artículo, nos interesan sobre todo aquellas alusiones que afectan a la imagen religiosa. En primer lugar, hay que decir que es precisamente este tipo de obras el único que se asocia estrechamente con el campesino. Y ello hasta tal punto, que cuando dos villanos de la comedia anónima Un pastoral albengue se encuentran un retrato (que era el género pictórico "urbano" por excelencia), uno de ellos pregunta si "es santo", a lo que su compañero responde despectivo:

Siempre has de hablar desatinos; santo es, pues está pintado ${ }^{11}$

Durante el Siglo de Oro había un tipo de campesino al que se asocia especialmente un nivel máximo de rusticidad, de manera que acabó por convertirse en un personaje tópico. Estamos hablando del sayagués, de cuya conversión en "tipo" con características definidas da fe el hecho de que frecuentemente interviniera en danzas junto con representaciones de otros grupos étnicos o naciones, como gitanos, negros, asiáticos, etc. ${ }^{12}$ En una anónima relación de la vida de Santa Teresa aparece uno de estos personajes, y se describe su actitud ante unas fiestas. En esos versos se encuentran la mayor parte de las características que definen esta clase de citas: En el Valle de Olid se celebran unas fiestas en honor de Teresa, a las que acude un tosco sayagués, / porque hasta el más ignorante / es siempre amigo de ver.

10 Obras escogidas de Lope de Vega, ed. F. C. SÁINZ DE ROBLES (Madrid: Aguilar, 1964, 4." ed.), II, p. 407b.

11 Obras de Lope de Vega, ed. M. MENÉndez Pelayo (Madrid: Atlas, 1963-1972), XXXIX, p. $210 b$. 
Tras entrar en la iglesia observa absorto las suntuosas colgaduras, el rico adorno del altar, la gran cantidad de cera que ardía, la música que solemnizaba los oficios y las ricas joyas que adomaban la imagen de la santa, ante todo lo cual abrió la boca admirado. Sin embargo, este deslumbramiento no afectó seriamente su sentido común, que le llevó a decir:

Señora doña Teresa,

Dios guarde a vuestra merced, que a fée que en talle, y cara pareceis mujer de bien ${ }^{13}$

Vemos, pues, que se juega con varios tópicos: en primer lugar con el de la existencia de un nivel de percepción ínfimo; también con el de la ingenuidad campesina; $y$, por último, con la idea de que la fe o la devoción no sólo no están reñidas con la falta de ccultura", sino que en ocasiones aparecen incluso más fuertemente enraizadas en personas poco instruidas.

La mayor parte de las citas inciden en estos aspectos, y en ellas se juega generalmente con el contraste entre la escasa cultura y el fuerte sentido común que demuestra el campesino cuando se trata de hablar de temas religiosos, aunque lo exprese a través de un lenguaje tosco. Así, por ejemplo, en la obra Conceptos divinos de Lope de Vega, se incluye esta canción:

Esto le dijo a un retrato / que estaba en una pared, de la Inmaculada Virgen, / un villano sayagués:

Apenas os conocía / con el sol en buena fe, mas yo le parezca a Dios, / como vos me parecéis.

En el hermoso Cordero / que en vuestros brazos traeis, por el remedio del mundo, / conocí a vuesa merced. ¡Pardiobre, que aunque pintada, / amostráis un no sé qué, digo, de amor y de miedo, / que al fin sois madre del Rey! Oí decir a mi cura, / hablando más de una vez, que os hizo, el que madre os llama, / sin culpa antes de nacer ${ }^{14}$

12 José SIMON, Relaciones breves de actos públicos celebrados en Madrid de 1541 a 1650 (Madrid: C.S.I.C., 1982), pp. 35 y 36. En Madrid en 1599, una de las danzas del Corpus representó una boda sayaguesa. En Sevilla, en 1572 los roperos representaron una -Boda villana de Castillan, que se describe así: sllevavan un negro muy galán tañendo su flauta y tamboril, y otro tañendo una gaita çamorana, y a trechos bailaron en diversas partes de la plaça, y dieron buelta a la ciudad. El vestido, baile y çapateta, fue todo tan al natural como se haze en Castilla, y campos, y Sayago. ANONIMO, Relación... fiestas... Sevilla... Nacimiento del Príncipe Ntro. Sr. (Sevilla: Hernando Díaz, 1572), $7 v$.

13 ANONIMO, Vida y milagnos de la B. Madre Teresa de lesüs, s.l., si. s.a. (1614), 2r. Hay un ejemplar de este raro impreso en la Biblioteca Nacional de Madrid, V.E., 118-12.

14 Obras de Lope de Vega, ed. M. Menendez Pflayo (Madrid: Atlas, 1963-1972), VII, pp. $477-478$. 
Aunque con el tiempo las referencias a los sayagueses acabaron por convertirse en un útil recurso completamente tópico y fueron tan abundantes que dieron lugar a romances o poemas "a lo sayagués" ${ }^{15}$, no faltan testimonios que nos indican que llegó a difundirse la creencia de que, efectivamente, el sayagués era una persona apenas instruida, no sólo en lo que se refiere a su cultura general sino incluso desde el punto de vista religioso, lo que en parte contradice algunos de los versos anteriores. Por ejemplo, el padre Durán, en el prólogo de su segunda parte de la Historia de las Indias de Nueva España, escrito a finales del siglo XVI, al tratar de las posibilidades de evangelización de la población novohispana escribe:

En España hay otra gente tan ruda y basta como ellos, o poco menos, como es la gente que en muchas partes de Castilla hay, conviene a saber, hacia Sayago, las Batuecas y en otros muchos rincones de provincias, donde son los hombres de juicio extrañamente toscos y groseros y sobre todo faltos de doctrina, mucho más que estos naturales ${ }^{16}$

Con el tiempo, sin embargo, creemos que "sayagués" fue perdiendo su inicial vinculación con Sayago, es decir, con una comarca concreta, y fue convertido en apelativo de hombre rústico, gracias a un proceso similar al que llevó a utilizar el nombre de "talavera" para designar cualquier loza vidriada producida en España ${ }^{17}$.

La naturaleza eminentemente plástica y sensorial de la religiosidad espanola del Siglo de Oro no se circunscribió a la que practicaban las masas de población, pues definió también algunos de los más importantes intentos que llevaron a cabo destacadas órdenes religiosas para reformar los métodos de meditación y hacer más eficaz la labor pastoral. Un ejemplo, bien conocido

15 Uno de los sonetos que se leyeron en Pastrana con motivo de las fiestas por la beatificación de Santa Teresa estaba hecho "a lo pastoril sayagués". Su primera estrofa dice así: "O Teresa y que bien meeys parecido / sobre las andas oy en nuessa ygreja. / En viendoos se quedó mi alma perpleja, / y se me hué de sopito el sentido. En DIEGO DE SAN JOSÉ, Compendio de las solenes fiestas que en toda España se bicienon en la Beatificación de la N.M.B. Teresa de lestús (Madrid: Vda. de Alonso Martín, 1615), II, 87r. Por su parte, José de VALDIVIELSO, en su obra En gracia del arte noble de la pintura (en CALVO SERRALLER, op. cit., p. 350) escribe: *Y aunque es verdad católica que el arte no puede dar alma a las imágenes, se las dan con los afectos todos los que con culto religioso las reverencian, implorando con fe viva las intercesiones de lo que representan, como yo lo dije en una redondilla de un romance sayagués, a la milagrosa image de Nuestra Señora de la Novena (...):

"Pues si no pudo valiente/ daros el alma el pincel,

podéis, Virgen, alabaros / que os la dan quantos os ven"..

16 Fray Diego DURÁN, Historia de las Indias de Nueva España (Madrid: Banco Santander, 1991 y 1992), II, p. 345.

" José PÉREz VIDAl, "Talavera, apelativo de loza", Olaria. Boletim du Museu de Ceramica Popular Portuguesa, I (1968), pp. 4-14. 
por todos, nos ahorrará mayores comentarios. Nos referimos al método ignaciano de "composición de lugar", que busca activar la imaginación mediante referentes plásticos para situar en un contexto físico preciso el objeto de la meditación, con lo que ésta gana en eficacia ${ }^{18}$. Esta fórmula no se hizo exclusiva de la Compañía de Jesús, y fue ampliamente utilizada. Un ejemplo entre muchos nos lo proporciona Fray Diego de Leyba, quien, refiriéndose al venerable fray Diego Romera, comenta:

Mirando en una ocasión con los ojos interiores a Christo nuestro bien en el prendimiento, quando aquellos crueles sayones le amarraron sus soberanas manos atrás, con tanta fuerça, pues poniendo el verdugo su sacrilego pie encima de los braços de lesús, tan fuertemente tiraba de el cordel, que le hizo verter sangre por todas las uñas de sus muy delicados dedos, el padre fray Diego le ofrecía las telas de su coraçón, que las pusiesse en medio, para que no le lastimasen los cordeles, y esto con muy amorosos afectos, entonces se le desapareció la Imagen de Christo nuestro bien ${ }^{19}$.

Una tarea que todavía está por hacer, pero que daría excelentes resultados para el conocimiento de algunos aspectos de la imaginación del hombre de esa época, es el estudio de la relación (presumiblemente muy estrecha) entre los lugares en los que se ubican este tipo de meditaciones y el espacio que crean las frecuentes visiones, y su comparación con las convenciones figurativas que utilizan pintores y dramaturgos para reconstruir sobre el lienzo o la escena los ámbitos donde tienen lugar las visiones o los milagros.

Los párrafos anteriores han querido mostrar, a un nivel muy general, algunos aspectos relacionados con el comportamiento ante la imagen sagrada en la España del Siglo de Oro. En los siguientes vamos a estudiar un caso concreto, que nos demuestre hasta qué punto en la relación entre el hombre y ciertos santos y en el conocimiento que se tenía de éstos jugaron un papel fundamental sus imágenes. Este análisis lo haremos a través de expresiones o citas literarias cortas que tengan un indudable origen iconográfico.

Antes de entrar en detalles queremos hacer dos observaciones que sirvan para situar el material que vamos a utilizar en su contexto. En primer lugar, hay que decir que la mayor parte de las citas proceden, por su propia naturaleza, de personas a las que el hecho mismo de practicar la escritura colocaba intelectualmente por encima de la mayoría de sus contemporáneos. Sin embargo, aunque sea un dato que no hay que perder de vista, creemos que no constituye un obstáculo insalvable que impida extrapolar sus reacciones ante la imagen sagrada, equiparándolas a las que podía tener el resto de la población. En realidad, la mayor parte de los personajes que se citan

18 Véase, entre otros, Julián GÁllego, Visión y simbolos en la pintura española del Siglo de Oro (Madrid: Aguilar, 1972), pp. 212 y ss.

19 Vida del venerable Fray Diego Romera (México: Juan Ribera, 1684), 24r-v. 
pertenecen al santoral tradicional, cuya iconografía era bien conocida por todọ, y además no sólo frecuentemente este tipo de alusiones se localizan en contextos argumentales populares, sino que, gran parte de ellas, aparecen en un género de audiencia masiva como es el teatro, en el que existía un importante caudal de significados comprensibles por todos.

Las referencias iconográficas hay que estudiarlas también teniendo en cuenta el contexto general de las alusiones al santoral tradicional en la literatura. En este sentido, es altamente significativo el hecho de que las únicas ocasiones donde se nombra alguno de estos personajes con más frecuencia que para relacionarlo con su iconografía son aquellas en las que se utilizan como hitos del calendario. Es decir, en la literatura de la época (excluyendo, claro está, la hagiográfica), los santos actúan sobre todo como referencias cronológicas que jalonan el ciclo anual campesino o en función de las ceremonias o usos sociales relacionados con su festividad; abundan también las alusiones iconográficas; y son relativamente escasas las citas de carácter narrativo en las que se refiere un hecho relacionado con su vida, a no ser que hubiera tenido importancia en la creación de su iconografía. Todo ello nos lleva al convencimiento de que el conocimiento del santoral tradicional se sustentaba sobre dos pilares: los usos ceremoniales y ritos festivos relacionados con su culto, y la tradición iconográfica. Esto trajo como consecuencia una identificación entre el santo y su atributo ${ }^{20}$, lo que a su vez produjo en ocasiones una tergiversación de la propia biografía de aquél, como comentó Francisco Sánchez de las Brozas durante su proceso inquisitorial:

Le preguntaron que por qué pintaban a Sancta Luçía con unos ojos en un plato, y por qué era abogada de los ojos; y este confesante respondió que no era lo que ellos pensaban, que no avía de ser tan boba o tan necia que se sacase los ojos para dallos a otros; y que muchas cosas cree el vulgo que están por esas iglesias que no tenemos más autoridad que pintallas el pintor como le pareció ${ }^{21}$

Pero a pesar de reparos como éste y otros semejantes, lo cierto es que se fue extendiendo un código que permitía a la mayor parte de la población identificar muchos de los personajes que veía pintados o esculpidos. Bernardino de Villegas, por ejemplo, dedica un largo párrafo a criticar la costumbre de vestir suntuosamente algunas imágenes, lo que considera una

20) Véase Julián Gállego, El funcionamiento de la imagen sacra en la sociedad andaluza del Barrocon, en el catálogo de la Exposición Pedro de Mena 1628-1688 (Málaga: Junta de Andalucía, 1989), p. 33.

21 Citamos por Herrero, op. cit., 182. El tema de la problemática relación entre los santos y sus atributos o su propia representación corpórea viene de atrás. Así, el anónimo autor del Viaje de Turquía compara a los que escriben sobre cautivos sin haber estado en cautividad con slos pinctores que pintan a los ángeles con pluma, y a Dios Padre con barba larga, y a Sant Miguel con amés a la marquesota, y al diablo con pies de cabra. Ed. García Salinero (Madrid: Cátedra, 1980), p. 89. 
práctica profana; pero al mismo tiempo es perfectamente consciente de que los atributos de las santas proporcionan las claves suficientes como para reconocer tras tanta deshonesta riqueza a un personaje concreto ${ }^{22}$.

Durante toda la época que estudiamos se suceden las intervenciones eclesiásticas con objeto de controlar la iconografia. Con ellas no sólo se pretendía evitar representaciones que atentaran contra el decoro, sino que se trataba también de unificar narraciones y atributos para que pudieran ser universalmente reconocidos. La imagen sagrada, a su valor como vehículo para propiciar la relación entre el fiel y su religión, unía su utilidad como garante y testigo de la tradición. De hecho, son frecuentes las ocasiones en las que se trata de probar un hecho importante en la historia de la Iglesia o de alguno de sus héroes invocando la existencia de una tradición iconográfica que lo avala. Del cuidado que ponía Roma en la codificación iconográfica es prueba que durante las ceremonias de canonización se fije la imagen *oficial" del nuevo santo ${ }^{23}$; y de la conciencia generalizada sobre la importancia de este tipo de tradición da fe el siguiente diálogo que se incluye en El Cardenal de Belén, de Lope de Vega:

ROMA. Angel santo, que guiaste / por tantos mares y peñas este divino Tobías. / ¿Cómo pintaré en mi Iglesia de Gerónimo la imagen?

ANGEL. Roma venturosa, espera; / que te le quiero mostrar, porque a retratalle aprendas, / y desta suerte le pintes.

(San Jerónimo se descubra en unos peñascos, colgado el hábito y capelo de un árbol, con el canto en la mano, el pecho descubierto, el león a los pies, y mirando a un Christo) ${ }^{24}$

De lo fundamental que era la tradición pictórica a la hora no sólo de representar, sino incluso de imaginarse los santos, puede darnos idea el estudio de las indicaciones escenográficas que aparecen en las comedias de la época. En este sentido, las que nos interesan son aquellas en las que para completar la descripción de un personaje o una escena se remite a su iconografía tradicional, mediante la fórmula "como le pintan", u otras similares. Manuel Ruiz Lagos ya ha hecho un inventario de las que aparecen en el teatro calderoniano; por lo que aquí nos vamos a limitar a dar algunos apuntes sobre las que se encuentran en las obras de Lope de Vega.

22 Que a veces, duda un hombre, si las adorará por Santa Lucía o Santa Catalina, o si apartará los ojos, por no ver la profanidad de sus trajes: porque en sus vestidos y adorno no parecen santas del cielo, sino damas del mundo: y a no estar Santa Catalina con su espada en la mano, y Santa Lucía con sus ojos en el plato (...) nadie diría que eran santas, ni vírgenes honestísimas, como lo fueron. La esposa de Cbristo, instruida con la vida de Santa Lutgarda (c. 1635). Citamos por Julio CARO BAROJA, Las formas complejas de la vida religiosa (Madrid: Akal, 1978), p. 116.

23 Sobre ello ha insistido Emile Male, op. cit.

24 Comedias escogidas de Lope de Vega (Madrid: Atlas, 1946-1952), III, p. 607. 
Las fórmulas de este tipo se emplean fundamentalmente para tres clases distintas de descripciones: de las características físicas de un personaje; sus atributos iconográficos o una escena determinada. Las primeras son poco abundantes, pues escasean los personajes identificables simplemente por su aspecto corporal. Entre ellos se encuentra Job, que en La limpieza no manchada sale "viejo, muy lleno de llagas, como le pintan" ${ }^{25}$; o, por supuesto, el diablo. Sin embargo como la iconografía de este ser dejaba bastante margen a los artistas, no es fácil encontrar una alusión a un demonio "como le pintan"; aunque sí a diablos que toman la forma de seres con formas y atributos más estandarizados, como los sátiros:

Sale un demonio en forma de sátiro, media máscara hasta la boca, con cuernos; hasta la cintura, un desnudillo de cuero blanco, y de la cintura a los pies, de piel, a hechura de cabrón, como le pintan ${ }^{26}$

Con mayor frecuencia encontramos referencias a los atributos iconográficos que identifican a los santos. Santo Domingo, por ejemplo, aparece «con el perro y el hacha, como le pintan, y el azucena en la mano ${ }^{27}$; mientras que San Agustín se encuentra "vestido de obispo, con su cayado y la iglesia en la mano, como le pintan, la Herejía a los pies con algunos libros 28.

Pero la codificación de las imágenes no sólo se refiere a la formación de un lenguaje que permitía identificar a unos cuantos personajes, pues había también episodios importantes de la historia sagrada para los que la tradición artística había encontrado una forma de expresión que se creía idónea, lo que hizo que apenas sufrieran variaciones compositivas. Como es natural, la mayor parte eran escenas evangélicas, muchas de las cuales se habían representado desde los inicios del arte cristiano occidental y a través de los siglos habían ido alcanzando una representación específica. Un par de ejemplos nos servirán para describir este fenómeno: Una didascalia de El Rosario de Nuestra Señora indica: "Baja San Gabriel como le pintan en la Encarnación" ${ }^{29}$, mientras que en el acto tercero de El nacimiento de Cristo se instruye: "Descúbrase el portal, Iosef y la Virgen con el Niño en las manos, el rey Baltasar de rodillas, besándole el pie,

25 Obras de Lope de Vega, ed. M. MEnÉndez PELAYo (Madrid: Atlas, 1963-1972) (BAE, 187), p. $160 \mathrm{~b}$.

26. Obras de Lope de Vega, ed. M. MENEndEz PELAYO (Madrid: Atlas, 1963-1972) (BAE, 215), p. 381b.

27 La devoción de rosario, en Obras de Lope de Vega, ed. E. CoTtaRELo (Madrid: Real Academia Española, 1916-1930), II, p. 116a.

28 El divino africano, en Obras de Lope de Vega, ed. M. MENÉnDEZ PELAYO (Madrid: Atlas, 1963-1972), (BAE, 177), p. 362a-b.

29. Obras de Lope de Vega, ed. M. MEnEndez PELAYo (Madrid: Atlas, 1963-1972), VII, p. $132 b$. 
los otros dos a los lados como pinta la tabla de los Reyes. ${ }^{30}$. Un simple repaso a repertorios de pinturas españolas de esta época es suficiente para descubrir variados ejemplos de obras que se ajustan a estas descripciones, o adivinar cuáles serían los movimientos del arcángel Gabriel sobre el escenario.

En ocasiones se encuentran en este tipo de didascalias fenómenos curiosos que nos advierten que a pesar de lo codificado que estaba el lenguaje de la imagen sagrada, también se admitian importantes contaminaciones o trasvases figurativos. Una acotación escénica de Adonis $y$ Venus (.Venus, que baja del cielo en una nube cerrada, de la cual salen muchos pajarillos. Algunos cupidillos en la nuben) conducirá inmediatamente la imaginación del lector hacia la característica "Inmaculada-Ascensión" que tanto y tan bien se prodigó en la pintura española de esa época ${ }^{31}$.

Una parte importante de las alusiones iconográficas que aparecen en la literatura del Siglo de Oro revelan explícitamente su relación con una imagen o una tradición figurativa. Entre ellas hay algunas en las que se va más allá y el tema del discurso (frecuentemente satírico) es precisamente el origen de esta tradición. Quevedo, por ejemplo, en su Sueño del infierno, reflexiona así sobre las representaciones de Judas:

Hícele así, y vi a Judas, que me holgué mucho, cercado de sucesores suyos. Y de su cara no sabré decir sino que me sacó de la duda ser barbirrojo, como le pintan los españoles para hacerle extranjero, o barbinegro, como le pintan los extranjeros por hacerle español, porque él me pareció capón (...)

-...Pero una cosa querría saber de ti: ¿por qué te pintan con botas y dicen por refrán slas botas de Judas??

-No porque yo las trujese - respondió-; mas quisieron significar, poniéndome botas, que anduve siempre de camino para el infierno y por ser despensero. $Y$ así se han de pintar todos los que lo son ${ }^{32}$

El tema interesaba por sus posibilidades paródicas, como prueba el que en una academia festiva que se celebró en el Buen Retiro en 1637 una de las dos materias propuestas fuera "Por qué a Judas pintan con barba rubia ${ }^{33}$.

30 Obras de Lope de Vega, ed. M. MENÉndez Pflayo (Madrid: Atlas, 1963-1972), (BAE, CLIX), p. 251a.

31 Obras escogidas de Lope de Vega, Ed. F. C. SÁINZ DE RoBlEs (Madrid: Aguilar, $1967,3 .^{\text {a }}$ ed.), III, p. 554 a.

32 Sueños y discursos, ed. F. MALdonado (Madrid: Castalia, 1980), pp. 135-137.

33 Noticias de Madrid desde el año de 1636 basta el de 1638, Biblioteca Nacional de Madrid, Mss. 18447, 49v-50r. Guarín, un personaje de la comedia de Lope, La obediencia laureada, maldice del amor y se pregunta: "¿Por qué te pintan niño, hermoso, afable / ... / mejor fuera, villano interesable, / pintarte con la bolsa como a Judas.. Obras de Lope de Vega, ed. E. CotARELo (Madrid: R.A.E., 1916-1930), XIII, p. $142 a$. 
En la mayor parte de las referencias, sin embargo, no se advierte ninguna preocupación por el origen de una iconografía que, por habitual, no da lugar a ningún tipo de duda. En general se organizan todas de una forma parecida, $e$ individualmente poco añaden al conocimiento de las tradiciones figurativas o al estudio de la penetración del conocimiento de los santos entre la población. Su valor lo da precisamente su abundancia, que nos muestra lo muy profundamente que estaba instalada la asociación mental, prácticamente automática, entre el personaje de la historia sagrada y su atributo o su forma canónica de representación. En los párrafos siguientes vamos a ver algunos de estos ejemplos de alusiones a santos en las que se hace referencia explícita a su iconografía.

Frecuentemente estas citas actúan para, por vía de comparación, describir las características de algún personaje o alguna situación. Aunque en algunas ocasiones se utilizan historias mitológicas para hacerlo ${ }^{34}$, abundan más los casos protagonizados por santos; y mientras que aquéllas suelen aparecer relacionadas con miembros de las clases cultas, éstos se encuentran generalmente en contextos populares, lo que no deja de ser significativo. A veces su sentido es irónico, como en el siguiente diálogo de Obras son amores:

MARIN. Rey Mago es aqueste rey.

JULIA. ¿Cómo?

MARIN. ¿No los ves pintados / con una copa, en Belén, sin soltalla de la mano? JuLA. Bien dices, Rey Mago es ${ }^{35}$

Al igual que hemos visto ocurría en las didascalias teatrales, en el resto de las citas literarias las referencias al Antiguo y el Nuevo Testamento se organizan frecuentemente en torno a escenas, mientras que las historia sagrada posterior tiene como puntos de referencia personajes concretos en vez de episodios. Al ejemplo de la Epifanía se puede sumar el de la tentación de Eva, al que se alude en Las bizarrias de Belisa ${ }^{36}$.

Dado lo muy amigos que fueron los escritores de utilizar las alusiones iconográficas en contextos satíricos o irónicos, no debe extrañarnos que tres de los personajes más frecuentemente nombrados sean San Miguel, San Jorge y San Antón, a quienes acompañan el diablo, el dragón y el cerdo, respectivamente. Al primero hace alusión Luna en su Segunda Parte del Lazarillo de Tormes, cuyo protagonista cuenta:

34 Véase Javier PORTús, Lope de Vega y las artes plásticas (Relaciones entre pintura y poesía en la España del Siglo de Oro (Madrid: Universidad Complutense, 1992), pp. 275 y ss.

35 Obras de Lope de Vega, ed. E. COTARELo (Madrid: R.A.E., 1916-1930), VIII, p. 190b.

36 Para caracterizar a las mujeres, el Conde dice: Como de un género son. / Saben, para herir, tentar / la flaqueza de la espada. / ¿No has visto a Eva pintada, / y que la viene a engañar / con el rostro de mujer, / que la culebra tomó? / Pues este ejemplar les dio / para engañar y vencer / a mujeres con mujeres. Obras de Lope de Vega, ed. E. CotARELo (Madrid: R.A.E., 1916-1930), XI, p. 461a. 
Y los muchachos me comenzaron a correr y hacerme tanto mal, que por huir de su furia me entré en una iglesia y puse junto al altar mayor, donde cantaban una misa. Como los clérigos vieron aquella figura, que sin duda parecía al diablo que pintan a los pies de San Miguel, dieron a huir ${ }^{37}$.

A veces, sin embargo, la alusión a San Miguel se utiliza para ponderar la gallardía de algún personaje, como ocurre en El valenoso catalán, donde Clavela asegura que don Ramón de Moncada actuó frente a los turcos -como en pintura se nota / el arcángel San Miguel, / que a los demonios arroja" ${ }^{38}$.

La sierpe de San Jorge era bastante famosa, como veremos más adelante, y no faltan alusiones explícitas a su integración en la iconografia del santo. Castillo Solórzano, en Las bappías de Madrid, nos habla de un escritor que estaba redactando una comedia titulada "La dama sierpe", y que "pensaba que por lo extraordinario se la habían de pagar los actores [sic, por autores] muy bien, y engañábase, que no había cosa más vista en la corte que damas sierpes, que lo pudieran ser en un retablo de San Jorge ${ }^{39}$.

San Antón, por su parte, era conocido por el cochino que le acompaña, lo que fue muy aprovechado entre los escritores como vehículo paródico. Así, un anónimo Discurso de la viuda de veinte y cuatro maridos nos habla de un personaje que después de salir espantado de casa de una mujer "nacida en otro siglo, que de puro seca aun no tiene legañas", anduvo por la ciudad «buscando un altar y imagen de San Antón, para suplicarle me apartase de esta tentación fiera; puedo decir con verdad que en ninguna de sus tablas y imágenes he visto cosa más horrible ni espantosa ${ }^{40}$.

37 B. C. ARIBAU (ed.), Novelistas anteriores a Cervantes (Madrid: Atlas, 1944), p. 128b. G. HIDALGO, en sus Diálogos de apacible entretenimiento incluye unos versos sobre las criadas, que dicen así: "Decidme, señor Fabricio, / ansí Dios os dé mil dones, / ¿Quién metió estos mascarones / en vuestra casa y servicio? / ... / No os juntéis a algún retablo / de San Miguel sin dragón, / porque luego habrá cuestión / quien ha de quedar por diablo. Adolfo de CASTRO (ed.), Curiosidades bibliográficas (Madrid: Atlas, 1950), p. 288b.

38 El valeroso catalän. En Obras de Lope de Vega, ed. M. MEnÉndez Pelayo (Madrid: Atlas, 1963-1972) (B.A.E., t. 198), p. 190a.

39 Novela picaresca española, ed. A. ZAMORA VICENTE (Barcelona: Noguer, 1976), III, p. $76 \mathrm{a}$.

40 Adolfo de CASTRO (ed.), Curiosidades bibliográficas (Madrid: Atlas, 1950), pp. 520-521. Unos versos del soneto de Quevedo Buscona busca coche para el sotillo la víspera. dice así:

-BUSCONA. ¿Sabeis de alguno por aquí con coche?

ESCUDERO. San Antón tiene coche en el retablo.

Buscona. Bien decís. Pues pedídselo esta noche, que yo, por ir en coche, iré en cochino.

Citamos por José Delerto, También se divierte el pueblo (Madrid: Espasa-Calpe, 3. ${ }^{2}$ ed., 1966), p. 39. 
La obra más valiosa de toda nuestra literatura del Siglo de Oro para comprender hasta qué punto era estrecha la convivencia con las imágenes es Los melindres de Belisa, que no por casualidad fue escrita por Lope de Vega, un autor extraordinariamente receptivo tanto hacia las artes plásticas como hacia el mundo popular. La comedia gira en torno a una dama caprichosa y sus relaciones con una pareja que se hacen pasar por esclavos. Pero lo que aquí nos interesa es que una parte importante de los recursos que utiliza Lope para describir el carácter melindroso de la protagonista tienen como punto de referencia la iconografía. En algún caso se trata de obras de arte concretas, que podían verse en los templos madrileños, como la estatua del rey Don Pedro el Cruel que estaba en Santo Domingo:

Tenía grandes los ojos, / y algo el mirar espantado; /

Si así mira enamorado / ¿qué hará después con enojos?

Muy bien despedido va; / que vi la figura en él

del rey Don Pedro el Cruel, / que en Santo Domingo está

La mayor parte de las citas, sin embargo, no hacen alusión a ninguna imagen específica, sino que se refieren a iconografias comunes que, por sus especiales características, podían afectar al carácter impresionable de la protagonista. Entre ella y su madre se desarrolla el siguiente diálogo:

$\begin{array}{ll}\text { LISARDA. } & \text { A San Jerónimo iré. } \\ \text { BELISA. } & \text { ¡Ay! no, madre. } \\ \text { LISARDA. } & \text { ¿Por qué causa? } \\ \text { BELISA. } & \text { Tiene a los pies un león, / que siempre que entro me espanta; y } \\ & \text { una vez, madre, no dudes / que ha de saltarme a la cara. } \\ \text { LISARDA. } & \text { Pues no nos pongan el coche; / que a San Miguel a pie basta. } \\ \text { BELISA. } & \text { Y ¿no es nada el de los pies, / junto al peso de las almas? }\end{array}$

Se trata de diálogos deliciosos por lo vivos, y en su exageración nos ayudan a comprender hasta qué punto el hombre del Siglo de Oro mantenía una convivencia estrecha con las imágenes de los santos, que ocupaban un lugar destacado en su imaginación. Más adelante, la misma Belisa aumenta el catálogo de las representaciones que le impresionaban:

Di en no ir a misa / donde hubiese el ángel / que venciendo pintan sierpes infernales. / Viendo a San Cristóbal / forma de gigante, me dieron mil veces / desmayos mortales ${ }^{41}$

Un estadio intermedio entre las alusiones explícitas a pinturas o esculturas que hemos visto en las páginas anteriores y las referencias implícitas que estudiaremos más adelante, lo forma un grupo destacado de citas en las que el nombre del santo aparece precedido por el indefinido unn, que nos remite

41 Comedias escogidas de Lope de Vega (Madrid: Atlas, 1946-1952), I, pp. 321b, 319 y 325 . 
a la existencia de una forma ejemplar o paradigmática que cristaliza en una iconografia determinada. Sancho, un personaje de la comedia de Rojas Zorrilla Donde no bay agravios no bay celos indica a su interlocutor que a no ser por la mediación de su esposa "Os había de poner / como un San Sebastián"; María Zayas nos habla de un rostro aaunque flaco y macilento, tan hermoso, que parecía un ángelm; Fray Diego de Leyba, para describir la penosa situación de fray Diego Romero asegura que estaba thecho un varón de dolores"; y Mateo Alemán da un paso más en la asociación entre un modelo iconográfico y un personaje, indicando más precisamente sus parecidos. Así, hace decir a Guzmán: .Con la buena presencia y gravedad que me lo dijo, su buen talle, la cabeza calva, la barba blanca, larga hasta la cinta, un báculo en la mano, me representaba un San Pablo" ${ }^{42}$.

Con bastante frecuencia las alusiones al santoral tradicional se realizan recurriendo a los atributos iconográficos de sus protagonistas, mucho más que a narraciones concretas, aunque sin indicar expresamente su vinculación con una obra de arte. Las citas de este tipo son muy abundantes, y todas juntas nos prueban hasta qué punto fue estrecha la convivencia con las imágenes, y éstas ayudaron a formar la imaginación de nuestros antepasados. Casi todas las referencias lo son a personajes que vivieron antes de la Edad Moderna, cuya iconografía había ido fijándose con el paso del tiempo, hasta alcanzar una forma arquetípica. En los siguientes párrafos vamos a hacer un rápido repaso a este fenómeno, seleccionando de entre la multitud de alusiones aquellas que nos parecen más significativas.

San Jorge, en parte cristianización del mito de Perseo ${ }^{43}$, estaba tan asociado al dragón con el que combatió, que cuando se intentaba matar una araña se invocaba su nombre ${ }^{44}$, que salía a relucir también cuando se hablaba

42 Francisco Rojas ZORRILlA, Comedias escogidas, ed. R. MESONERO ROMANOS (Madrid: Atlas, 1952), p. 159a. María ZAYAS, Desengaños amorosos, ed. A. YllaRA (Madrid: Cátedra, 1983), p. 252. Diego de LEYBA, Vida del Venerable Fray Diego Romero (México: Juan Ribera, 1684), 57r. Mateo ALEMÁN, Guzmán de Alfarache, en Novelistas anteriores a Cervantes, ed. B. C. ARIBAU (Madrid: Atlas, 1944), p. 240 a.

43 Javier PORTús, ‘Difusión y transformaciones de un tema clásico en el Siglo de Oro: la liberación de Andrómedan, Cuadernos de Ante e Iconografía, II, 4 (1989), pp. 84-92.

44 .Y llega y dale un terrible pescozón, diciendo: "SSant Jorge!" Dijo el Conde: "QQué es esto?" Respondió: "Señor, abatí a vuestra señoría una grande araña por el pescuezoL. DE PINEDO, Libro de chistes, en A. PAZ Y MELA (ed.), Sales españolas (Ma-drid: Atlas, 1964), pp. 113-114. La expresión .San Jorge mata la araña ya aparece en G. CORREAs, Vocabulario de refranes y frases proverbiales, ed. L. COMBET (Bourdeaux: Université, 1969), p. 269. En la obra de Lope Los pleitos de Ingalaterra, el rey, después de sorprender al Conde intentando abrazar a su esposa, exclama:. $\mathrm{Si}$; iMas, por Dios, que he de ser / el San Jorge desta araña!. En Obras de Lope de Vega, ed. E. COTARELo (Madrid: R.A.E., 19161930), VIII, p. 503a. 
de sierpes ${ }^{45}$. Cuando Félix, en El ruiseñor de Sevilla anuncia que el ruiseñor ha llegado, recibe la siguiente contestación irónica del criado Riselo:

y el cuervo de San Antonio, / que viene a traerle el pan;

pero no le faltarán / tentaciones del demonio ${ }^{46}$

San Antón aparece frecuentemente en situaciones cómicas, y esto no tanto por sí mismo cuanto por las posibilidades paródicas de su atributo, el cochino ${ }^{47}$. San Lucas es recordado frecuentemente en contextos taurinos ${ }^{48}$; San Lorenzo, cuando se trata de parrillas y asados ${ }^{49}$, y de San Roque y Tobías son universalmente conocidos sus perros ${ }^{50}$. Uno de los personajes más nombrados es San Miguel, cuya sola mención se asocia automáticamente al ser que le suele acompañar, el demonio ${ }^{51}$. También abundantes son las alusiones a San Juan Bautista y su dedo, que dio lugar al dicho "Hasta que

45 .En viendo tan fiera sierpe/ encomendéme a San Jorge, / y a San Antón, que la tuve / por una de sus visiones". M. FARIA, Jardín de Apolo (Madrid: Juan González, 1634), 44r.

46 Obras de Lope de Vega, ed. M. MENÉndez PELAYo (Madrid: Atlas, 1963-1972), XXXII, p. $129 \mathrm{~b}$.

47 "SANCHA: Y aun por el santo verraco/ de San Antón, vos prometo que si el chuzo vos espeto, / que vos faga un buen foraco."

L. DE VEGA, Las famosas asturianas, ed. A. ZAMORA VICENTE (Salinas, 1982), p. 66. Existe un entremés anónimo titulado $E l$ cerdo de San Antón egún C. DE LA BARRERA, Catálogo bibliográfico y biográfico del teatro antiguo español (Madrid, 1860), p. 643.

48 -FABIO: Una vez el diablo quiso / que un torillo boquinero / ... / me acometió por un lado, / y yo, misas ofreciendo / al santo que de su libro / sacro fascistol le ha hecho"

Amor secreto hasta celos, en Obras de Lope de Vega, ed. E. COTARELo (Madrid: R.A.E., 1916-1930), III, p. 419b.

49 -En la cama de cordeles / (o la parrilla de cuerdas), / asándome de calor, / sin ser San Lorenzo me tuestan. A. Polo DE Medina, Poesía. Hospital de Incurables, ed. D. DiAz REVENGO (Madrid: Cátedra, 1987), p. 138.

so "COSME: Juntos las noches y días, / y tú, muy fuera de ti, / tras él de aquí para allí, / como el perro de Tobías.

LOPE DE VEGA, No son todos ruiseñores, en Obras de Lope de Vega, ed. M. MENÉNDEZ PELAYO (Madrid: Atlas, 1963-1972), XXXII, 175a. No eran raras expresiones como ¡Válgame el alano de San Roque!, que aparece en la comedia de Tirso de Molina La elección por la virtud. En Obras dramáticas completas, ed. B. DE LOS Ríos (Madrid: Aguilar, 1946), I, p. $226 b$.

51 .Y si San Miguel he sido, / galán a su parecer, / él parece Lucifer / que a sus pies está rendido. A. DURÁN, Romancero general (Madrid: Atlas, 1945), p. 539. Es un romance anónimo. Sobre la popularización de este arcángel en el folklore puede verse A. CaSTILLO DE LUCAS, :San Miguel, defensor y sanador de los cuerpos y de las almas, R.D.T.P., XVII (1961), pp. 145-156. 
San Juan baje el dedo" ${ }^{52}$. San Martín, por su parte, es inseparable de su media capa ${ }^{53}$, mientras que San Sebastián lo es de las flechas que perforaron su cuerpo ${ }^{54}$. Entre las santas, Inés se relaciona con el cordero ${ }^{55}$, y Lucía con los ojos, lo que en alguna ocasión ha servido a los escritores para ironizar sobre la expresión galante de ofrecer los ojos". Lope de Vega, por ejemplo, incluye en El llegar en ocasión el siguiente diálogo:

MARQUÉs. Sólo la quiero ofrecer / los ojos con que la veo.

FENISA. Cierto que es gran devoción; / chacéisla Santa Lucía? ${ }^{56}$

La importancia de este tipo de citas, de las que aquí hemos ofrecido una simple selección, estriba fundamentalmente en su elevado número, en el carácter popular de muchas de ellas y en su frecuente utilización con un sentido paródico accesible a todos los lectores u oyentes. Todo ello nos muestra hasta qué punto era no sólo conocida sino también familiar la iconografía del santoral tradicional para la sociedad española del Siglo de Oro. También es indicativo de lo mucho que influyó la información plástica en la imaginación del pueblo español, que usó de los atributos de los santos que veía esculpidos o pintados para crear expresiones, o como vehículo para formar alusiones cómicas.

Del conocimiento generalizado del código es prueba también el hecho de que, sobre todo en el teatro, se aluda a un santo haciendo mención no

52 Manuel Faria tiene un poema "A San Juan Bautista, mostrando con el dedo el Corderom [Divinas y bumanas flores (Madrid, Diego Flamenco, 1624), 135v]. Lope de Vega, en un "Romance de burlas a San Juan Bautista", escribe: "Dicen que al Cordero y Dios / vuestro dedo santo apuntan. En Al Smo. Sacramento en su fiesta. Justa de... Toledo..., (Toledo: Pedro Rodríguez, 1609), s.p.
53 .TOMÁS:
Dile que eres San Martín.
MARTIN:
No soy sino su caballo.

ERIFILA:

Que no me pesara, digo, /el santo que dices fueras;

que si lo fueras, partieras / tu media capa conmigo.

LOPE DE VEGA, Los locos de Valencia, ed. J. AGLiRRF. (Barcelona, 1977), p. 227. Alusiones similares aparecen en las comedias de Lope La obediencia laureada y El poder del discreto, así como el soneto de Góngora que empieza « $\mathrm{Oh}$, bien haya la bondad. Véase A. CASTILLO DE LUCAS, "Tradiciones populares sobre San Martín y la capa", R.D.T.P., XXVI (1970), pp. 139-149.

54 .Aquel mancebito / que me vio en la iglesia / de San Sebastián / me tiró mil flechas. Lope de VegA, El acero de Madrid, ed. L. Bergounioux (París, 1971), p. 116.

55 "LIMON: Di tu nombre.

INES: $\quad$ El de la santa / con el cordero en los brazos.

LOPE DE VEGA, Amar sin saber a quien, en Comedias escogidas de Lope de Vega (Madrid: Atlas, 1946-1952), II, p. 447a.

36 Obras de Lope de Vega, ed. M. MENÉNDEZ PELAYO (Madrid: Atlas, 1963-1972), XXXI, p. $67 a$. 
a su nombre, sino a algunos de los objetos o escenas que lo identifican. En Amar sin saber a quien uno de sus personajes se refiere al monasterio de San Jerónimo de esta manera:

Subí, y piqué al monasterio / del santo, que, como carta, hizo sello de una piedra / sobre nema colorada ${ }^{57}$

Por su parte, Inés, en La villana de Getafe, alude así a la torre de San Sebastián:

Mas pasando un día / ... / una cierta calle, / no lejos de adonde al santo flechado / hacen una torre ${ }^{58}$

En otras ocasiones, el escritor usa precisamente el nombre de un santo para que el lector, acostumbrado a verlo representado en pinturas y esculturas, se imagine a algún personaje. El tantas veces citado Lope alude a un ermitaño "que parecía hombre principal, que con venerable cabello y barba representaba un Crisóstomo o Basilio" ${ }^{59}$. Este mismo escritor utiliza una técnica similar en un contexto rústico, que nos indica que mantuvo los ojos bien abiertos a su paso por Galicia:

Pues yo os abrazo, mi vida. / ¿Qué maridito, qué ojos, qué copete, qué barba! / Santantón parece el hombre en ermita de Galicia ${ }^{\text {ro }}$.

JAVIER PORTÚS PÉREZ

A través de alusiones a santos, extraídas de la literatura del Siglo de Oro, en este artículo se ha tratado de ponderar la importancia que la tradición iconográfica tuvo en el conocimiento que el hombre de esa época poseia sobre el santoral tradicional.

Through references to saints, taken out from the Golden Age literature, this paper has tried to assert how important the iconographic tradition was on the level of knowledge which the man of that time had of the traditional saints.

57 Obras de Lope de Vega, ed. E. COTARELO (Madrid: R.A.E., 1916-1930), II, p. 287a.

58 Obras de lope de Vega, ed. E. CotARElo (Madrid: R.A.E., 1916-1930), X, p. 369b.

59 LOPE DE VEGA, El peregrino en su patria, ed. J. B. AVALLE-ARCE (Madrid, Castalia, 1973), p. 161.

60 No son todos ruiseñores, en Obras de Lope de Vega, ed M. MENÉndez PELAYO (Madrid: Atlas, 1963-1972), XXXII, p. 176a. 